DOI 10.15290/cnisk.2018.01.04.03

MGR AGNIESZKA DROZDOWSKA

orcid.org/0000-0003-2713-7958

Uniwersytet w Białymstoku

\title{
Zarys codzienności wojennej kobiet z guberni suwalskiej i obwodu białostockiego w latach 1914-1915
}

\section{Streszczenie}

Życie codzienne podczas trwania wojny uległo diametralnej zmianie. Zmieniły się postawa ludności cywilnej i jej priorytety. Ciężkie i tragiczne doświadczenia wojenne nie uszlachetniły wszystkich ludzi, a wręcz przeciwnie. Wojna i perspektywa braku możliwości życia na godnym poziomie wielu ludziom otwierały furtkę do wyzwolenia niemoralnych zachowań. W artykule tym zaprezentowano cztery aspekty wojennej rzeczywistości: strach, aprowizację, szpiegostwo i demoralizację. Bazę źródłowa pracy stanowi cykl reportaży Białystok $w$ lunie światowej pożogi wojennej ${ }^{1}$, zawierający wspomnienia białostoczan spisane w 1934 r. w „Echu Białostockim”, oraz wspomnienia Laury de Turczynowicz When the Prussians Came to Poland. The Experiences of an American Woman during the German Invasion² wydane w $1916 \mathrm{r}$.

Słowa kluczowe: życie codzienne, I wojna światowa, kobiety, strach, aprowizacja, szpiegostwo, demoralizacja

1 Białystok $w$ tunie światowej pożogi wojennej, „Echo Białostockie” 1934, nr 220-329.

2 L. de Turczynowicz, When the Prussians Came to Poland. The Experiences of an American Woman during the German Invasion, New York 1916 [online], [Dostęp: 06.01.2018]. Dostępny w World Wide Web: <http://bit.ly/2jfxgoQ>. 


\title{
OUTLINE OF WARTIME LIFE OF WOMEN FROM THE SUWALKI GOVERNORATE AND THE BIALYSTOK PROVINCE IN THE YEARS 1914-1915
}

\begin{abstract}
The outbreak of the war brough many dramatic changes to everyday life and affected the attitude of the civil population and its priorities. Difficult and tragic war experiences did not ennoble all people, on the contrary. The war and the prospect of being unable to live on a decent level for many people opened the door to liberation of immoral behaviour. The article presents four aspects of the reality of the war: fear, food supply, espionage and demoralization. The primary source for the work was a series of reportages Bialystok in the times of world-wide conflagration, containing the memories of Białystok residents in 1934 in "Echo Białostockie" (Echo of Białystok) and the memories of Laura de Turczynowicz When the Prussians Came to Poland. The Experiences of an American Woman during the German Invasion issued in 1916.
\end{abstract}

Keywords: daily life, World War I, women, fear, food suply, espionage, demoralization

Wydarzenia I wojny światowej przez wiele lat pozostawały na uboczu badań historycznych koncentrujących się na dziejach II wojny światowej. Coraz częściej jednak pojawiaja się prace poświęcone tematyce społecznej podczas Wielkiej Wojny³. Większość z nich kreuje pozytywny wizerunek ludności cywilnej, uciemiężonej przez wojnę i aktywnie walczącej o niepodległość Ojczyzny. Problematyka codzienności wojennej w guberni suwalskiej i obwodzie białostockim stanowiła przedmiot badań przede wszystkim historyków zwiąanych z tym obszarem, m.in. Adama Dobrońskiego ${ }^{4}$ i Daniela Grinberga ${ }^{5}$. Szczególna uwagę na sytuację i aktywność kobiet z północno-wschodniej części Królestwa Polskiego

\footnotetext{
3 J. Snopko, Wstęp [w:] Wielka Wojna poza linia frontu, red. D. Grinberg, J. Snopko, G. Zackiewicz, Białystok 2013, s. 9-11.

4 Historia Białegostoku, red. A. Dobroński, Białystok 2012; A. Dobroński, Ku wolności: I wojna światowa. Dramaty i nadzieje [w:] Historia województwa podlaskiego, red. Idem, Białystok 2010, s. 169-183.

5 Wielka Wojna poza linia..., op. cit.; Lata Wielkiej Wojny. Dojrzewanie do niepodległości 1914-1918, red. D. Grinberg, J. Snopko, G. Zackiewicz, Białystok 2007.
} 
podczas Wielkiej Wojny zwrócili także Małgorzata Dajnowicz i Andrzej Matusiewicz ${ }^{6}$.

Bazę źródłowa artykułu stanowi cykl reportaży historycznych BiaŁystok $w$ Łunie światowej pożogi wojennej ukazujący się od 15 sierpnia do 5 grudnia 1934 r. w „Echu Białostockim”, zdeponowanym obecnie w Bibliotece Narodowej w Warszawie. Według założeń redakcji wspomnienia miały ukazywać się codziennie, nie udało się jednak tego spełnić. Wydarzenia prezentowane na łamach gazety miały opisywać cztery etapy Wielkiej Wojny na terytorium miasta ${ }^{7}$. Cykl reportaży rozpoczał się od artykułów Białystok przed dwudziestu laty... ${ }^{8}$ oraz Wspomnienia $z$ przed dwudziestu lat... ${ }^{9}$, w których redaktor gazety Antoni Faranowski zapraszał białostoczan do aktywnej współpracy spisania wspomnień o I wojnie światowej. Dwudziestoletnia perspektywa czasu oraz cenzura umniejszają wiarygodność źródła. Ponadto należy pamiętać, że artykuły miały zapewnić poczytność pisma wśród czytelników, dlatego do „pikantnych" szczegółów z życia ówczesnych białostoczan trzeba podchodzić $z$ dystansem ${ }^{10}$. Mało wiarygodne w reportażu wydaja się być także cytowane dialogi ${ }^{11}$. Cykl Białystok $w$ tunie światowej pożogi wojennej był złączeniem w całość wspomnień różnych białostoczan. Błędne jest zatem przypisywanie przez niektórych historyków wszystkich tych wspomnień Stefanowi Brzostowskiemu ps. „Chmielnicki”, byłemu komendantowi

\footnotetext{
6 M. Dajnowicz, Everyday Life and Duties of Polish Women in the Rural Provinces of North-East Poland During the First World War, „Woman's History Review” 2017, Vol. 26, Iss. 4, s. 597-607, [online], [Dostęp: 08.01.2018]. Dostępny w World Wide Web: <http://bit. ly/ 2rTFQh5>; Eadem, Kobiety polskie z ziem pólnocno-wschodnich Królestwa Polskiego wobec rewolucji 1905 roku i początków I wojny światowej (w świetle przekazów pamiętnikarskich) [w:] Kobiety w wojnach i konfliktach polityczno-spolecznych na ziemiach polskich $w$ pierwszej połowie XX wieku. Wybrane zagadnienia, red. T. Kulak, A. Chlebowska, Wrocław 2014, s. 83-100; Eadem, Działalność publiczna kobiet polskich na pograniczu ziem północno-wschodniej Polski (od końca XIX wieku do 1939 roku) [w:] Aktywność publiczna kobiet na ziemiach polskich. Wybrane zagadnienia, red. T. Pudłocki, K. Sierakowska, Warszawa 2013, s. 69-83; A. Matusiewicz, Kobiety w życiu spoleczno-kulturalnym Suwatk przed 1914 rokiem [w:] Zachodnie wzorce i wschodnie realia. Przedstawicielki elit prowincjonalnych w XIX i pierwszej połowie XX wieku, red. M. Dajnowicz, Białystok 2009, s. 103-124.

7 Białystok w lunie światowej pożogi wojennej, „Echo Białostockie”, 12.08.1934, nr 223.

8 Białystok przed dwudziestu laty..., „Echo Białostockie”, 9.08.1934, nr 220.

9 Wspomnienia z przed dwudziestu lat..., „Echo Białostockie”, 10.08.1934, nr 221.

10 A. Drozdowska, Kobiety z ziem Królestwa Polskiego i Obwodu Białostockiego podczas pierwszej wojny światowej, praca mag., Uniwersytet w Białymstoku, Białystok 2017, s. 12 .

11 Białystok $w$ tunie światowej pożogi wojennej. XI Kwiatuszki ewakuacyjne, „Echo Białostockie", 19.08.1934, nr 230.
} 
Polskiej Organizacji Wojskowej w Krypnie ${ }^{12}$. Jego wspomnienia zostały opublikowane jedynie w numerach 277-285 „Echa Białostockiego” w okresie 6-14 października 1934 r.

Wspomnienia Laury de Turczynowicz ${ }^{13}$ zostały opublikowane w 1916 r. w Stanach Zjednoczonych. Jak sugeruje Maciej Ambrosiewicz, wydanie wspomnień Laury, w których pozytywniej przedstawia ona postawę żołnierzy armii rosyjskiej niż niemieckiej, mogło stanowić zabieg manipulacyjny i propagandowy ${ }^{14}$. Wspomnienia spisane zostały w języku angielskim dość chaotycznie, co utrudnia ich rozumienie i uniemożliwia zlokalizowanie opisywanych miejsc ${ }^{15}$.

Wybuch Wielkiej Wojny wpłynął bezpośrednio na zmianę sytuacji kobiet $\mathrm{w}$ społeczeństwie ${ }^{16}$. Okres ten nie był tylko czasem poświęcenia i heroicznej walki o wolność i niepodległość Ojczyzny. Wojna wyzwoliła niemoralne zachowania wśród ludności cywilnej ${ }^{17}$. Pobór mężczyzn do wojska miał ogromny wpływ na życie kobiet ${ }^{18}$, gdyż to na ich barkach spoczał wówczas obowiązek zapewnienia rodzinie przetrwania podczas wojennej pożogi. Na dalszy plan zeszła aktywność kobiet rozbudzona rewolucją lat 1905-1907, tj. walka o równouprawnienie czy większy do-

\footnotetext{
12 A. Lechowski, Okupacja 1915-1919. Cukierpuszki i herbaciane hale, „Kurier Poranny”, 5.09.2015, [online], [Dostęp: 7.06.2017]. Dostępny w World Wide Web: <http://bit. ly/2sCkaDL $>$.

13 Laura de Turczynowicz z domu Blackwell urodziła się w Kanadzie w 1878 r. Młodość spędziła w Nowym Jorku, z którego wyjechała do Europy w celu dalszego studiowania. $\mathrm{Z}$ zawodu była śpiewaczką operowa, występowała m.in. w Bayreuth, Monachium. W Krakowie poznała polskiego szlachcica herbu Gozdawa - hr. Stanisława de Turczynowicz. Ślub wzięli w Krakowie, gdzie urodziła troje dzieci. Następnie mieszkali w Augustowie, z którego po wybuchu wojny musiała uciekać do Suwałk. Tam organizowała pomoc medyczna rannym żołnierzom i aktywnie uczestniczyła w działalności Czerwonego Krzyża.

14 M. Ambrosiewicz, Kiedy Prusacy wkroczyli do Polski: Wielka Wojna we wspomnieniach Laury Turczynowicz, „Rocznik Augustowsko-Suwalski” 2014, t. 14, s. 137.

15 Ibidem, s.131-139.

16 B. Urbanek, Idea opieki nad chorym na ziemiach polskich w latach 1809-1914, Wrocław 2003, s. 33-34, 89-90; J. Dufrat, Stan badań nad dziejami kobiet w Polsce - I wojna światowa, okres międzywojenny, II wojna światowa [w:] Dzieje kobiet w Polsce. Dyskusja wokół przyszłej syntezy, red. K.A. Makowski, Poznań 2014, s. 123-131; M. Dajnowicz, Everyday Life..., op. cit.

17 A. Lechowski, op. cit.

18 „Miejscowe pułki i sztaby odeszły w początkach sierpnia do rosyjskiej 2 Armii ("Narew») dowodzonej przez gen. Aleksandra Samsonowa. Miała ona z pozycji nadnarwiańskich uderzyć na Prusy Wschodnie" (A. Dobroński, Białystok: historia miasta, Białystok 1998, s. 108-109).
} 
stęp do edukacji. Najważniejsze stało się zapewnienie żywności i opieki medycznej najbliższym ${ }^{19}$.

Kobiety żyły w strachu nie tylko o mężów czy ojców powołanych do służby, lecz także w obawie o własne życie. Bez pomocy mężów nie były w stanie samodzielnie prowadzić gospodarstwa. Młode kobiety stały się obiektem pożądania pijanych żołnierzy. Samotność wzmagała strach przed gwałtami i rabunkami. Wojna zabrała poczucie bezpieczeństwa społecznego i stała się impulsem wyzwolenia niemoralnych zachowań zarówno wśród kobiet, jak i mężczyzn. Jak wynika $z$ analizy źródłowej, dla wielu kobiet wojna stała się okresem utraty pozycji społecznej i dobrego imienia. Paradoksalnie jednak podczas wojny dorobiły się one znacznych majątków ${ }^{20}$. Oczywiście nie należy uogólniać. Zdecydowana większość kobiet aktywnie włączyła się w działalność humanitarna i pomocową na rzecz rannych żołnierzy oraz potrzebujacych, co wynikało $z$ wielu czynników ${ }^{21}$. Aktywność pomocowa kobiet widoczna była jeszcze przed wybuchem I wojny światowej ${ }^{22}$, zwłaszcza w organizacjach o charakterze religijnym $^{23}$. Działalność emancypacyjna i aktywność społeczno-kulturalna kobiet została przerwana przez wybuch konfliktu zbrojnego i odsunięta w czasie ${ }^{24}$. Niektórym kobietom prócz oczywistej stereotypowej roli zajmowania się gospodarstwem domowym i pomocy rannym przypadła walka na froncie ${ }^{25}$.

\footnotetext{
19 M. Dajnowicz, Działalność publiczna kobiet..., op. cit., s. 76.

20 Białystok $w$ łunie światowej pożogi wojennej. CXXXXIV O niektórych bogaczach białostockich - CXXXXV Jak oficerskie kochanki wspierały... przemysł białostocki, „Echo Białostockie", 17.10.1934, nr 288.

21 A. Drozdowska, Kobiety a działalność Czerwonego Krzyża na ziemiach polskich zaboru rosyjskiego w latach 1914-1916 na podstawie wspomnień lekarza Czerwonego Krzyża oraz Laury de Turczynowicz, „Czasopismo Naukowe Instytutu Studiów Kobiecych” 2017, nr 1 (2), s. 73-89, DOI 10.15290/cnisk.2017.01.02.04.

${ }_{22}$ M. Dajnowicz, Everyday Life..., op. cit.; M. Piotrowska-Marchewa, Kobiety i filantropia. Uwagi o zaangażowaniu przedstawicielek polskich elit $w$ działalność dobroczynna XIX wieku [w:] Zachodnie wzorce..., op. cit., s. 49-63; D. Wawrzykowska-Wierciochowa, W kręgu miłości i bohaterstwa (z dziejów humanitaryzmu polskiego i prekursorów Czerwonego Krzyża), Warszawa 1965.

${ }^{23}$ M. Dajnowicz, Zachodnioeuropejskie wzorce emancypacyjne na polskiej prowincji w poczatkach XX w. Wpływ Elizy Orzeszkowej i Marii Konopnickiej na poglady i działalność przedstawicielek elit ziem pólnocno-wschodnich [w:] Zachodnie wzorce..., op. cit., s. 126. ${ }_{24}$ A. Matusiewicz, Kobiety w życiu społeczno-kulturalnym..., op. cit., s. 103-120; M. Dajnowicz, Zachodnioeuropejskie wzorce..., op. cit., s. 126-135.

25 M. Dajnowicz, Everyday Life..., op. cit.; Eadem, Kobiety polskie..., op. cit., s. 90; J. Dufrat, W służbie obozu marszałka Józefa Piłsudskiego. Zwiazek Pracy Obywatelskiej Kobiet (1928-1939), Kraków 2013, s. 23-75; M. Gawin, Spór o równouprawnienie kobiet 1864-1919, Warszawa 2015, s. 235-266.
} 
Zdeterminowana i aktywna postawa kobiet wobec trudności wojennych miała bezpośredni wpływ na zmianę ich sytuacji po zakończeniu wojny. Jednak ich działalność podczas codzienności wojennej nieodzownie łaczyła sie z opracowanymi w artykule czterema aspektami rzeczywistości, choć nie wszystkie kobiety doświadczyły jej w równym stopniu. Niemniej zdecydowana większość miała świadomość istnienia tych aspektów w lokalnej społeczności podczas trwania Wielkiej Wojny.

\section{Strach}

Brak pewności jutra rodził lęk i obawy o życie swoje, rodziny i najbliższych ${ }^{26}$. Uczucie to towarzyszyło nie tylko ludności wschodnich ziem Królestwa Polskiego uciekającej w 1915 r. przed armia niemiecką w głą Imperium Rosyjskiego ${ }^{27}$. Lęk budził się także w ludności cywilnej - zarówno miejskiej, jak i wiejskiej - pozostającej w swoich gospodarstwach mimo szerzonej propagandy o brutalności żołnierzy armii niemieckiej² .

Kobiety pozbawione mężów wziętych do służby wojskowej musiały zapewnić przetrwanie sobie i rodzinie. Znaczaca pomoc materialna uzyskiwały od rządu rosyjskiego, wobec wzrostu cen żywności wielkość udzielanych zapomóg okazała się jednak niewystarczająca. Samotność i natłok obowiazków, jakie im przypadły, wzmagały lęk. Wojna była niewiadoma przyszłości mimo to kobiety starały się zapewnić jedzenie, ogrzewanie i pieniądze, by móc przetrwać tę zawieruchę wojenną. Ale nie wszystkie postępowały zgodnie $z$ obowiazującymi normami moralnymi. Trudności wojenne i choroba najbliższych wpływały nie tylko na psychikę kobiet, lecz także na ich wygląd. Laura de Turczynowicz, patrząc w lustro, nie poznawała samej siebie, tak bardzo zmęczona była nieustannym czuwaniem przy chorych dzieciach i praca na rzecz rannych

\footnotetext{
26 M. Dajnowicz, Everyday Life..., op. cit.

27 A. Prymaka-Oniszk, Bieżeństwo 1915: zapomniani uchodźcy, Wołowiec 2016, s. 17-29; M. Korzeniowski, M. Mądzik, D. Tarasiuk, Tułaczy Los: uchodźcy polscy w imperium rosyjskim w latach pierwszej wojny światowej, Lublin 2007, s. 15-19; K. Sierakowska, Śmierć - Wygnanie - Głód $w$ dokumentach osobistych: ziemie polskie $w$ latach Wielkiej Wojny 1914-1918, Warszawa 2015, s. 136-186. Fotografie bieżeńców zdeponowane w Archiwum Akt Nowych w zespole Centralnego Komitetu Obywatelskiego zostały wydane w opracowaniu zatytułowanym Uchodźstwo polskie $w$ Rosji $w$ latach I wojny światowej, oprac. M. Korzeniowski, K. Latawiec, D. Tarasiuk, L. Żwanko, Lublin 2016.

28 A. Prymaka-Oniszk, op. cit., s. 26-29; K. Sierakowska, op. cit., s. 41-45, 59-72; M. Dajnowicz, Everyday Life..., op. cit.
} 
żołnierzy ${ }^{29}$. Działalność kobiet w organizacjach humanitarnych podczas Wielkiej Wojny była powszechnym zjawiskiem motywowanym wieloma czynnikami ${ }^{30}$.

Ogromny wpływ na kobiety miały rozłąka i utrata najbliższych. Niepewność i brak informacji o stanie zdrowia oraz losach członków rodziny potęgowały uczucie bezsilności i przygnębienia. Stan taki wzmagały także informacje $z$ frontu ${ }^{31}$. Uczucie osamotnienia i strata najbliższych miały bezpośredni wpływ na angażowanie się kobiet w organizacjach pomocowych. Kontakt $z$ innymi ludźmi i świadomość potrzeby pomagania rannym i potrzebującym stanowiły metodę na zapomnienie o własnych traumatycznych przeżyciach ${ }^{32}$.

Próba znormalizowania wojennej rzeczywistości w mieście i adaptacja do nowych warunków życia nie były łatwe. Uczestnictwo w wieczornych przedstawieniach wiąało się $z$ ryzykiem późnego powrotu i represjami za nieprzestrzeganie godziny policyjnej ${ }^{33}$. Mimo to życie kulturalne białostoczan podczas okupacji niemieckiej rozwijało się dość intensywnie. Organizowane za zgoda władz niemieckich koncerty, bale czy spektakle miały na celu nie tylko zbiórkę pieniędzy na pomoc dobroczynna, lecz także odwrócenie uwagi ludności od trudności wojennych i deficytu żywności ${ }^{34}$.

Według relacji Laury de Turczynowicz poczucie strachu i bezradności w wielu ludziach zbudziło potrzebę zawierzenia siebie i bliskich Bogu. Laura szukała pocieszenia i wskazówek w Piśmie Świętym. Codzienny stał się wówczas widok ludzi klęczących przed obrazem Matki Bożej Ostrobramskiej w Wilnie ${ }^{35}$. Nabożeństwa religijne odprawiane były też $\mathrm{z}$ rozkazu władz rosyjskich $\mathrm{w}$ podzięce za powodzenie $\mathrm{w}$ walce ${ }^{36}$. Nie-

\footnotetext{
29 L. de Turczynowicz, op. cit., rozdz. XVI.

30 B. Urbanek, op. cit., s. 33-34, 89-90; A. Drozdowska, Kobiety a działalność Czerwonego Krzyża..., op. cit., s. 73-89; P. Englund, Piękno i smutek wojny. Dwadzieścia niezwykłych losów z czasu światowej pożogi, przeł. E. Fabisiak, Kraków 2011, s. 92.

31 L. de Turczynowicz, op. cit., rozdz. XXV.

32 K. Sierakowska, op. cit., s. 21.

33 Białystok $w$ tunie światowej pożogi wojennej. CLXXII „Polizeistunde”, „Echo Białostockie", 2.11.1934, nr 304.

${ }^{34}$ Białystok $w$ tunie światowej pożogi wojennej. CCXVII Powódź... muzyki - CCXXVIII Działalność kulturalna, związki i partie polityczne, „Echo Białostockie”, 22-27.11.1934, nr 324-329.

35 L. de Turczynowicz, op. cit., rozdz. VIII, XV-XVI.

36 Białystok $w$ łunie światowej pożogi wojennej. VII Drang nach Osten, „Echo Białostockie", 18.08.1934, nr 229.
} 
stety dla wielu okrutna rzeczywistość wojenna pozostawała niepojęta, skutkiem czego bardzo dużo osób utraciło nadzieję i wiarę w Boga. Wśród nich były także małe dzieci ${ }^{37}$.

\section{Aprowizacja}

Susza i zabór zapasów żywności przez wojsko, zła dystrybucja towarów, zniszczenie przemysłu i rolnictwa, a wskutek tego brak pracy, stały się przyczyną niedoborów żywności wśród ludności cywilnej ${ }^{38}$. Wpłynęło to na wzrost cen żywności: chleba, makki, mięsa i cukru o 25\%. Produkty te nadal jednak były dostępne dla większości białostoczan. Głód już na początku wojny odczuła jedynie ludność uboga ${ }^{39}$. W celu zapewnienia dostępu do żywności wszystkim mieszkańcom Białegostoku władze niemieckie we wrześniu 1915 r. wprowadziły system kartkowy na chleb, przydzielajacc 2 funty, czyli 820 g, chleba na osobę. Porcja ta była stała i niezależna od wieku oraz płci $^{40}$. Deficyt mąki zaczęto likwidować poprzez dodawanie do produkcji chleba m.in. otrębów, sieczki, słomy, siekanych buraków czy zmielonych suszonych kasztanów ${ }^{41}$.

Niemcy wprowadzili też system kartkowy na ziemniaki - przydział miesięczny wynosił 34 funty na jedna osobę ${ }^{42}$. Nie uchroniło to jednak ludności przed deficytem ziemniaków, które nakazano zastępować brukwią. W tym celu wydawano nawet specjalne wskazówki dla kucharek, jak należy przyrządzać zamarzniętą brukiew. Pamiętny dla białostoczan stał się również nakaz dostarczania władzom niemieckim w mieście łupin $z$ kartofli. Przetwarzano je na „floki”, czyli gęsty i lepki suplement kaszy kartoflanej lub produkcji chleba ${ }^{43}$.

\footnotetext{
37 L. de Turczynowicz, op. cit., rozdz. XV.

38 K. Sierakowska, op. cit., s. 210-216.

39 Białystok $w$ lunie światowej pożogi wojennej. XXXVII Stan aprowizacji $w$ przededniu okupacji - XXXVIII Aprowizacja w pierwszych miesiacach okupacji, „Echo Białostockie”, 7.09.1934, nr 249.

40 Białystok $w$ tunie światowej pożogi wojennej. XXXIX Pierwsze ograniczenia - karty na chleb, „Echo Białostockie”, 7.09.1934, nr 249.

41 Historia Białegostoku..., op. cit., s. 324-325.

42 Białystok $w$ łunie światowej pożogi wojennej. XLVII Kartoffelkarten, „Echo Białostockie", 10.09.1934, nr 252.

43 Białystok w łunie światowej pożogi wojennej. LII Brukiew zamiast kartofli - LV Uniwersalny pokarm, „Echo Białostockie”, 12.09.1934, nr 254.
} 
Systemem kartkowym objęto także kaszę, choć wskutek licznych zachorowań po zjedzeniu zakazano jej spożywania ${ }^{44}$. W 1916 r. system kartkowy objął też cukier, który zastapiono sacharyną. Przydział kartkowy cukru na osobę wynosił $205 \mathrm{~g}$ na $10 \mathrm{dni}$, sacharyny zaś przydzielano 10 tabletek na tydzień. Deficyt tego produktu w tym okresie szczególnie zapadł w pamięć białostoczanom ze względu na demoralizację kobiet zwanych „cukier puszkami”45.

Kartki żywnościowe i produkty zastępcze, tj. sacharynę zamiast cukru, kwiat lipy jako herbatę i makkę drzewna, władze niemieckie wprowadzały na wszystkich okupowanych przez siebie terenach ${ }^{46}$. Pojawiły się imitacje m.in. masła, kawy, herbaty tworzone $z$ przepalonego jęczmienia, owsa czy suszonych jabłek i gruszek ${ }^{47}$. Duża liczba zamienników zadecydowała o wydaniu w 1917 r. ogólnych kartek żywnościowych na wszystkie produkty ${ }^{48}$. Systemem kartkowym nie objęto jednak mięsa, ale jego dostępność ograniczono, wprowadzając dni bezmięsne. Mięso legalnie można było nabyć jedynie w piątki i wtorki ${ }^{49}$.

Trudności aprowizacyjne i głód wyzwalały w białostoczanach wiele niemoralnych zachowań. Ograniczenia dostępności produktów spożywczych charakteryzowały się długimi kolejkami na ulicach miasta, w których dochodziło do kradzieży deficytowych artykułów ${ }^{50}$. Zmusiło to władze okupacyjne do postawienia straży przy punktach wydawania żywności ${ }^{51}$.

System kartkowy na produkty spożywcze bardzo słabej jakości wpłynął na rozwój handlu żywnościowego na tzw. czarnym rynku. Ze względu na zawyżone ceny produktów niewielu białostoczan mogło sobie jednak pozwolić na zakup żywności pozakartkowej. Dość powszechny

\footnotetext{
44 Białystok $w$ tunie światowej pożogi wojennej. LVI Dalsze ograniczenia aprowizacyjne LVIII Perłowa kasza czyli tzw. gwoździe, „Echo Białostockie”, 13.09.1934, nr 255.

45 Białystok w tunie światowej pożogi wojennej. LIX Cukier na karty - LXI Ogólne „skartowane” aprowizacji, „Echo Białostockie”, 14.09.1934, nr 255.

46 A. Dobroński, Ku wolności..., op. cit., s. 181.

47 Białystok $w$ łunie światowej pożogi wojennej. CXXIII Ersatz..., „Echo Białostockie”, 2.10.1934, nr 271.

48 Białystok $w$ lunie światowej pożogi wojennej. LIX Cukier na karty - LXI Ogólne „skartowane” aprowizacji, „Echo Białostockie”, 14.09.1934, nr 255.

49 Białystok $w$ łunie światowej pożogi wojennej. CXXIV Bezmięsne dni, „Echo Białostockie", 2.10.1934, nr 271.

50 Białystok $w$ łunie światowej pożogi wojennej. XL Za chlebem..., „Echo Białostockie”, 8.09.1934, nr 250.

51 Białystok $w$ tunie światowej pożogi wojennej. XLII Chleb pod eskorta kolb karabinowych, „Echo Białostockie”, 8.09.1934, nr 250.
} 
stał się widok kobiet $z$ workami na plecach, wędrujących noca do okolicznych wsi lub mniejszych miasteczek, takich jak Suraż, gdzie żywność była dużo tańsza niż w Białymstoku ${ }^{52}$.

Należy podkreślić, iż wielkość trudności aprowizacyjnych zależała od majętności ludzi przed wojną i w czasie jej trwania ${ }^{53}$. Konieczność zapewnienia bytu rodzinie, jedzenia i opału na zimę leżała wówczas w kwestii kobiet, które w większości przypadków pozbawione zostały mężów i ojców powołanych do służby wojskowej ${ }^{54}$. Wpłynęło to na zmianę tradycyjnego podziału ról życiowych, a następnie doprowadziło do wzrostu znaczenia kobiet ${ }^{55}$.

\section{Szpiegostwo}

Wśród wielu niemoralnych zachowań wojennych potępianych przez białostoczan podczas I wojny światowej było szpiegostwo. Donosiciele wbrew pozorom nie byli obdarzeni zaufaniem także przez władze carskie i niemieckie. Władza [niemiecka] uważała takich „doradców” za piesków, których można słuchać (...) ale liczyć się z nimi nie trzeba ${ }^{56}$. Udział w spotkaniach, podczas których rozmawiano nieprzychylnie na temat władz carskich, groził aresztowaniem i postawieniem zarzutu podejrzenia o szpiegostwo. Takie osoby były torturowane na przesłuchaniach tak mocno, że według wspomnień białostoczan, aż $90 \% \mathrm{z}$ nich traciło wówczas życie ${ }^{57}$. Nie wiadomo jednak, ile $z$ tych osób rzeczywiście było szpiegami, a ile przypadkowymi obywatelami miasta, którzy powtarzali zasłyszane plotki ${ }^{58}$.

W celu likwidacji tego zjawiska i utrudnienia działań na szkodę państwa władze niemieckie stacjonujace w Białymstoku wprowadziły

\footnotetext{
${ }_{52}$ Białystok $w$ tunie światowej pożogi wojennej. VI Brak żywności, „Echo Białostockie”, 28.08.1934, nr 239; Białystok w tunie światowej pożogi wojennej. CXIV Zakaz dowozu żywności - CXVII Bunt i muzyka, „Echo Białostockie”, 29.09.1934, nr 269.

${ }^{53}$ L. de Turczynowicz, op. cit., rozdz. XXVII-XXVIII; M. Dajnowicz, Everyday Life..., op. cit.

54 Białystok $w$ tunie światowej pożogi wojennej. VI Brak żywności, „Echo Białostockie”, 28.08.1934, nr 239.

55 J. Dufrat, Stan badań..., op. cit.; B. Urbanek, op. cit., s. 33-34, 89-90.

56 Białystok $w$ łunie światowej pożogi wojennej. IX Doradcy, „Echo Białostockie”, 29.08.1934, $\mathrm{nr} 240$.

57 Białystok $w$ tunie światowej pożogi wojennej. XII Szpiclokracja i expressjustycja, „Echo Białostockie", 20.08.1934, nr 231.

58 L. de Turczynowicz, op. cit., rozdz. XVI.
} 
wspomnianą wcześniej godzinę policyjna, która budziła lęk wśród zwykłych obywateli ${ }^{59}$. Ponadto ograniczono wyjazdy poza granice miasta. Należało wystapić $z$ wnioskiem do władz niemieckich w Kownie i czekać na decyzję. Wydanie pozwolenia i czas oczekiwania na przepustkę zależne były m.in. od miejsca docelowego wnioskodawcy. Na pozwolenie wyjazdu do Warszawy należało oczekiwać nawet około pół roku od złożenia wniosku ${ }^{60}$. Często atutem zwiększającym szanse uzyskania przepustki była przynależność do Czerwonego Krzyża ${ }^{61}$. Siostry Czerwonego Krzyża nie zawsze były jednak traktowane $z$ szacunkiem należnym osobom ratującym rannych żołnierzy. Po wkroczeniu armii niemieckiej do Suwałk siostry Rosyjskiego Czerwonego Krzyża traktowano jak szpiegów i według relacji Laury de Turczynowicz zdarzały się przypadki kar śmierci dla personelu medycznego. Osobom utrzymujacym kontakt $z$ personelem Rosyjskiego Czerwonego Krzyża również groziło podejrzenie o szpiegostwo na rzecz władz carskich ${ }^{62}$.

Mimo świadomości ludzi o karach za szpiegostwo wielu decydowało się na współpracę na rzecz wrogiej armii. Przyczyną tego były trudności wojenne, brak żywności i obawa przed utratą bliskich osób. Ofiarą kolaboracji była także Laura de Turczynowicz. Jedna z Żydówek doniosła oficerowi niemieckiej armii o zapasach żywności i alkoholu, skutkiem czego zabrano Laurze ostatnią butelkę wina potrzebną do leczenia jej synka. $Z$ kolei w innym miejscu Laura wspominała Żydówkę, która dzieliła się tym, co miała i poświęcała się na rzecz pomocy rannym żołnierzom ${ }^{63}$. Stąd jasno wynika, że nie należy uogólniać postaw poszczególnych osób do całej społeczności, do której należeli. Szpiegostwo pozwalało uzyskać pewne przywileje i zapewnić godne warunki życiowe podczas wojny. Wiązało się jednak $z$ ryzykiem utraty szacunku i zaufania lokalnej społeczności, możliwością wydania władzom okupacyjnym, a w konsekwencji nawet śmiercią.

\footnotetext{
59 Białystok $w$ tunie światowej pożogi wojennej. CLXXII „Polizeistunde”, „Echo Białostockie", 2.11.1934, nr 304.

60 Białystok $w$ tunie światowej pożogi wojennej. CLXLVI Bez swobody ruchu, „Echo Białostockie", 12.11.1934, nr 314.

61 L. de Turczynowicz, op. cit., rozdz. XIX.

${ }^{62}$ Ibidem, rozdz. XXV.

63 Ibidem, rozdz. XV, XXIII.
} 


\section{Demoralizacja}

Zmiana sytuacji, jaka nastapiła po wypowiedzeniu wojny, stała się swoistym przyzwoleniem na przekraczanie norm moralnych. Wojna była czasem, w którym demoralizacja społeczeństwa postępowała szybko, szerzyły się rozwiązłość kobiet i alkoholizm ${ }^{64}$. Nadużywanie spożycia alkoholu szczególnie widoczne było wśród żołnierzy walczacych w ciagłym strachu i niepewności o własne życie. Nadmierne ilości trunków pozwalały żołnierzom zmniejszyć strach przed wroga armia, ale często były też przyczyna niemoralnych zachowań wobec kobiet ${ }^{65}$.

Jak wynika $z$ opracowywanych źródeł, częstym zjawiskiem podczas wojny były gwałty i kradzieże. Taki fragment wojennej codzienności widoczny jest w pamiętniku Laury de Turczynowicz. Kobieta często wspominała o ofiarach przemocy stosowanej przez żołnierzy wobec ludności cywilnej. Nagminnie zdarzały się uprowadzenia młodych dziewcząt, pobicia i gwałty oraz kradzieże ${ }^{6 \sigma}$. Największe „żniwo” było wówczas, gdy żołnierze dostawali odgórne przyzwolenie na picie alkoholu po wygranej bitwie. Kobiety natenczas zamykały się w domach i nie podchodziły nawet do okien, by ich nie zauważono. O strachu przed gwałtem świadczyć może też informacja $z$ pamiętnika Laury, która bała się zakładać szlafrok i spała w ubraniu, w którym chodziła przez cały dzieńn ${ }^{67}$.

Demoralizacja, a wraz z nią choroby weneryczne szerzyły się także wśród ludności cywilnej. W celu monitorowania rozwoju tego zjawiska władze niemieckie w Białymstoku wydały nakaz stawiania się wszystkich mężczyzn na badania lekarskie każdego pierwszego dnia miesiąca. Gromadzono ich wówczas na jednym placu i rozbierano do naga, co według relacji białostoczan stanowiło traumatyczne doznanie ${ }^{68}$. Kontrole takie nie omijały również kobiet, choć nie wynikały one $z$ rozkazu armii niemieckiej, ale $z$ donosicielstwa sąsiadów. Powyciagano $z$ łóżek czcigodne matrony $i$ ich córeczki i odstawiano je do policji obyczajowej. Tam podda-

${ }^{64}$ T. Boruta, Wplyw duchowieństwa rzymskokatolickiego na postawy ludności wiejskiej $w$ latach I wojny światowej (na przykładzie południowego Podlasia) [w:] Lata Wielkiej Wojny..., op. cit., s. 237.

65 L. de Turczynowicz, op. cit., rozdz. XXI.

66 Ibidem, rodz. XV-XVI.

67 Ibidem, rozdz. XV.

68 Białystok w łunie światowej pożogi wojennej. XIV Schwanzenparade, „Echo Białostockie", 31.08.1934, nr 242. 
wano je bardzo upokarzającemu badaniu ${ }^{69}$. Najczęściej jednak oskarżenia o nierządność i choroby weneryczne okazywały się bezpodstawne. Stanowiły jedynie porachunki wrogich rodzin, które na długo wprowadzały niewinne kobiety w poczucie wstydu przed lokalna społecznością i strachu przed następną kontrola.

Mimo to Białystok jako miasto „frontowe” zgromadził w swym obszarze dużą liczbę prostytutek i szpiegów z różnych stron. Brak mężczyzn powołanych do służby wojskowej w armii carskiej wielu samotnym kobietom stworzył sytuację do czynnego korzystania $z$ uroków życia. Nie należy wykluczać, iż takie decyzje ówczesnych białostockich dam były powiązane $z$ nadzieją na uzyskanie lepszych warunków życia podczas wojennej rzeczywistości. Mocna konkurencję lokalnym i przybyłym do Białegostoku na „gastrole” córom Koryntu robiły niektóre, „dobrze urodzone" panie i panny tutejsze $e^{70}$. Zjawisko to wiazało się $z$ niebezpieczeństwem rozprzestrzeniania się chorób wenerycznych, także wśród żołnierzy. Władze niemieckie, chcąc temu zapobiec i zmniejszyć skalę, podjęły decyzję o urządzaniu obław na kobiety podejrzane o prostytucję. Złapane na ulicach lub wyprowadzone $z$ mieszkań były przewożone do publicznej łaźni. Tam rozbierano je do naga, obcinano włosy, a następnie przeprowadzano lekarskie oględziny, nierzadko stosujac wobec nich przemoc. Zdrowe kobiety były wypuszczane do domu $z$ nakazem stawiania się na cotygodniowe kontrole. Natomiast zarażone kobiety przewożono do szpitala $^{71}$.

Powszechnym zjawiskiem wśród białostoczanek było zawieranie bardzo bliskich relacji z oficerami armii niemieckiej. Kochanki niemieckich żołnierzy złośliwie nazywano „cukier puszkami”, gdyż potrafiły uzyskać wszelkie produkty deficytowe, np. cukier, sacharynę ${ }^{72}$. Poprzez tę znajomość stawały się pośrednikiem między okupantem a mieszkańcami miasta, którym załatwiały wszystkie sprawy i potrzebne pozwolenia ${ }^{73}$.

\footnotetext{
${ }^{69}$ Białystok $w$ tunie światowej pożogi wojennej. XV Nocne kontrole, „Echo Białostockie”, 31.08.1934, nr 242.

70 Białystok $w$ tunie światowej pożogi wojennej. IV Panika, „Echo Białostockie”, 16.08.1934, $\mathrm{nr} 227$.

71 Białystok $w$ tunie światowej pożogi wojennej. XXI Walka z prostytucja, „Echo Białostockie", 2.09.1934, nr 244; Białystok $w$ tunie światowej pożogi wojennej. LXVIII Obok szpitala, „Echo Białostockie”, 16.09.1934, nr 257.

${ }^{72}$ Historia Białegostoku..., op. cit., s. 325; A. Lechowski, op. cit.

73 Białystok w łunie światowej pożogi wojennej. CXXXIX Gdzie diabeł nie może... - CXXXX „Cukierpuszkies”, „Echo Białostockie”, 16.10.1934, nr 287.
} 
Dzięki handlowi niedostępnymi na rynku produktami zapewniały sobie dostanie życie także po zakończeniu wojny ${ }^{74}$. Znacząca informacja na temat pochodzenia prostytutek została zawarta w numerze 295 „Echa Białostockiego" z 24 października 1934 r. Napisano bowiem, że w większości przypadków prostytucją w Białymstoku zajmowały się Żydówki, co wynikać miało $z$ ich trudnej sytuacji materialnej ${ }^{75}$.

\section{Podsumowanie}

Rzeczywistość wojenna wielu kobietom uświadomiła ich siłe psychiczną i umiejętność zapewnienia bezpieczeństwa dzieciom. Dzięki aktywnemu włączeniu się kobiet w działalność organizacji humanitarnych mężczyźni zaczęli doceniać ich troskę i pomoc oraz pracę, jaką wykonywały, by ratować rannych żołnierzy i pomagać potrzebujacym.

Jak wynika $z$ zachowanych wspomnień, wszechobecnym aspektem codzienności wojennej był strach, choć pozostałe czynniki, tj. aprowizacja, szpiegostwo i demoralizacja, również nie należały do rzadkości. Kobiety żyły w strachu, bo na ich barki spadł trud zapewnienia żywności i opału na zimę oraz prowadzenia gospodarstwa rolnego. Poczucie lęku rodziło się w nich w sposób szczególny jako wynik propagandy rosyjskiej na temat brutalności żołnierzy armii niemieckiej wobec ludności cywilnej. Nadmierne spożywanie alkoholu wielokrotnie było przyczyna gwałtów i grabieży dokonywanych przez żołnierzy obu armii. Kobiety bały się wówczas wychodzić $z$ domów. Strach w nich budziły także podejrzenia o szpiegostwo i obławy na prostytutki. Kobiety $z$ „dobrych domów” bały się utraty reputacji i szacunku lokalnej społeczności w wyniku nieprawdziwych oskarżeń swoich dawnych wrogów. Strach często motywował kobiety do przekraczania granic moralności społecznej.

Powyższa charakterystyka wojennej codzienności kobiet guberni suwalskiej i obwodu białostockiego stanowi jedynie zarys problematyki. Strach, kłopoty aprowizacyjne, szpiegostwo i demoralizacja stanowiły codzienność nie tylko na omawianym terytorium, lecz także na wszystkich ziemiach dotkniętych działaniami wojennymi, choć skala zjawiska

\footnotetext{
${ }^{74}$ Bialystok $w$ tunie światowej pożogi wojennej. CXXXXIV O niektórych bogaczach białostockich - CXXXXV Jak oficerskie kochanki wspierały... przemyst białostocki, „Echo Białostockie", 17.10.1934, nr 288.

75 Białystok $w$ tunie światowej pożogi wojennej. CLVII Dlaczego przeważnie Żydówki..., „Echo Białostockie”, 24.10.1934, nr 295.
} 
zapewne była różna. Wymienione aspekty nie sa jedynymi problemami wojennej rzeczywistości i nie wyczerpuja badanego zagadnienia. Dane źródłowe stanowia punkt wyjścia dla przyszłych badań w tym zakresie oraz uzupełnienie istniejącej już nielicznej literatury na temat dziejów I wojny światowej w obwodzie białostockim i w guberni suwalskiej.

\section{Bibliografia}

\section{Źródła}

Białystok przed dwudziestu laty..., „Echo Białostockie”, 9.08.1934, nr 220. Białystok $w$ łunie światowej pożogi wojennej, „Echo Białostockie”, 12.08.1934, $\mathrm{nr} 223$.

Białystok w łunie światowej pożogi wojennej. IV Panika, „Echo Białostockie”, 16.08.1934, nr 227.

Białystok w łunie światowej pożogi wojennej. VI Brak żywności, „Echo Białostockie", 28.08.1934, nr 239.

Białystok $w$ lunie światowej pożogi wojennej. VII Drang nach Osten, „Echo Białostockie", 18.08.1934, nr 229.

Białystok $w$ tunie światowej pożogi wojennej. IX Doradcy, „Echo Białostockie", 29.08.1934, nr 240.

Białystok $w$ łunie światowej pożogi wojennej. XI Kwiatuszki ewakuacyjne, „Echo Białostockie”, 19.08.1934, nr 230.

Białystok $w$ lunie światowej pożogi wojennej. XII Szpiclokracja i expressjustycja, „Echo Białostockie”, 20.08.1934, nr 231.

Białystok $w$ tunie światowej pożogi wojennej. XIV Schwanzenparade - XV Nocne kontrole, „Echo Białostockie”, 31.08.1934, nr 242.

Białystok w tunie światowej pożogi wojennej. XXI Walka z prostytucja, „Echo Białostockie", 2.09.1934, nr 244.

Białystok $w$ tunie światowej pożogi wojennej. XXXVII Stan aprowizacji w przededniu okupacji, „Echo Białostockie”, 7.09.1934, nr 249.

Białystok w lunie światowej pożogi wojennej. XL Za chlebem..., „Echo Białostockie", 8.09.1934, nr 250.

Białystok $w$ tunie światowej pożogi wojennej. XLII Chleb pod eskorta kolb karabinowych, „Echo Białostockie”, 8.09.1934, nr 250. 
Białystok $w$ tunie światowej pożogi wojennej. XLVII Kartoffelkarten, „Echo Białostockie", 10.09.1934, nr 252.

Białystok $w$ łunie światowej pożogi wojennej. LII Brukiew zamiast kartofliLV Uniwersalny pokarm, „Echo Białostockie”, 12.09.1934, nr 254.

Białystok $w$ łunie światowej pożogi wojennej. LVI Dalsze ograniczenia aprowizacyjne - LVIII Perłowa kasza czyli tzw. gwoździe, „Echo Białostockie”, 13.09.1934, nr 255.

Białystok w lunie światowej pożogi wojennej. LIX Cukier na karty - LXI Ogólne „skartowane” aprowizacji, „Echo Białostockie”, 14.09.1934, nr 255.

Białystok $w$ tunie światowej pożogi wojennej. LXVIII Obok szpitala, „Echo Białostockie", 16.09.1934, nr 257.

Białystok $w$ lunie światowej pożogi wojennej. CXIV Zakaz dowozu żywności - CXVII Bunt i muzyka, „Echo Białostockie”, 29.09.1934, nr 269.

Białystok $w$ lunie światowej pożogi wojennej. CXXIII Ersatz... - CXXIV Bezmięsne dni, „Echo Białostockie”, 2.10.1934, nr 271.

Białystok $w$ łunie światowej pożogi wojennej. CXXXIX Gdzie diabeł nie może... - CXXXX „Cukierpuszkies”, „Echo Białostockie”, 16.10.1934, $\mathrm{nr} 287$.

Białystok $w$ łunie światowej pożogi wojennej. CXXXXIV O niektórych bogaczach białostockich - CXXXXV Jak oficerskie kochanki wspierały... przemysł białostocki, „Echo Białostockie”, 17.10.1934, nr 288.

Białystok $w$ tunie światowej pożogi wojennej. CXLVI Bez swobody ruchu, „Echo Białostockie”, 12.11.1934, nr 314.

Białystok $w$ tunie światowej pożogi wojennej. CLVII Dlaczego przeważnie Żydówki..., „Echo Białostockie”, 24.10.1934, nr 295.

Białystok w łunie światowej pożogi wojennej. CLXXII „Polizeistunde”, „Echo Białostockie", 2.11.1934, nr 304.

Białystok $w$ lunie światowej pożogi wojennej. CCXVII Powódź... muzyki CCXXVIII Działalność kulturalna, zwiazki i partie polityczne, „Echo Bialostockie", 22-27.11.1934, nr 324-329.

Turczynowicz Laura de, When the Prussians Came to Poland. The Experiences of an American Woman during the German Invasion, New York 1916 [online], [Dostęp: 06.01.2018]. Dostępny w Word Wide Web: <http://bit. ly/2jfxgoQ>.

Wspomnienia z przed dwudziestu lat..., „Echo Białostockie”, 10.08.1934, nr 221. 


\section{Opracowania}

Ambrosiewicz Maciej, Kiedy Prusacy wkroczyli do Polski. Wielka Wojna we wspomnieniach Laury Turczynowicz, „Rocznik Augustowsko-Suwalski” 2014, t. 14, s. 131-139, ISSN 1730-9875.

Boruta Tadeusz, Wpływ duchowieństwa rzymskokatolickiego na postawy ludności wiejskiej w latach I wojny światowej (na przykładzie południowego Podlasia) [w:] Lata Wielkiej Wojny. Dojrzewanie do niepodległości 1914-1918, red. Daniel Grinberg, Jan Snopko, Grzegorz Zackiewicz, Białystok : Wydawnictwo Uniwersytetu w Białymstoku, 2007, ISBN 978-837431-142-7.

Dajnowicz Małgorzata, Działalność kobiet polskich na pograniczu ziem pótnocno-wschodniej Polski (od końca XIX wieku do 1939 roku) [w:] Aktywność publiczna kobiet na ziemiach polskich. Wybrane zagadnienia, red. Tomasz Pudłocki, Katarzyna Sierakowska, Warszawa : Wydawnictwo Neriton, 2013, s. 69-83, ISBN 978-83-7543-262-6.

Dajnowicz Małgorzata, Everyday Life and Duties of Polish Women in the Rural Provinces of North-East Poland During the First World War, „Woman's History Review" [online], t. 26, DOI 10.05.2016, s. 597-607, [Dostęp: 08.01.2018]. Dostępny w World Wide Web: <http://bit.ly/2rTFQh5>.

Dajnowicz Małgorzata, Kobiety polskie z ziem pótnocno-wschodnich Królestwa Polskiego wobec rewolucji 1905 roku i poczattków I wojny światowej ( $w$ świetle przekazów pamiętnikarskich) [w:] Kobiety $w$ wojnach $i$ konfliktach polityczno-społecznych na ziemiach polskich $w$ pierwszej połowie XX wieku. Wybrane zagadnienia, red. Teresa Kulak, Agnieszka Chlebowska, Wrocław : Wydawnictwo Chronicon, 2014, s. 83-100, ISBN 978-83-938172-7-6.

Dajnowicz Małgorzata, Zachodnioeuropejskie wzorce emancypacyjne na polskiej prowincji w poczatkach XX w. Wplyw Elizy Orzeszkowej i Marii Konopnickiej na poglady i działalność przedstawicielek elit ziem północno-wschodnich [w:] Zachodnie wzorce i wschodnie realia. Przedstawicielki elit prowincjonalnych w XIX i pierwszej połowie XX wieku, red. Małgorzata Dajnowicz, Białystok : Instytut Historii Uniwersytetu w Białymstoku; Drozdowo : Muzeum Przyrody, 2009, s. 125-138, ISBN 978-83-9242677-6. 
Dobroński Adam, Białystok. Historia miasta, Białystok : Zarząd Miasta, 1998, ISBN 83-907103-5-8.

Dobroński Adam, Ku wolności: I wojna światowa. Dramaty i nadzieje [w:] Historia województwa podlaskiego, red. Adam Dobroński, Białystok : Instytut Wydawniczy Kreator, 2010, s. 169-183, ISBN 978-83-7344057-9.

Drozdowska Agnieszka, Kobiety a działalność Czerwonego Krzyża na ziemiach polskich zaboru rosyjskiego w latach 1914-1916 na podstawie wspomnień lekarza Czerwonego Krzyża oraz Laury de Turczynowicz, „Czasopismo Naukowe Instytutu Studiów Kobiecych” 2017, nr 1 (2), DOI 10.15290/cnisk.2017.01.02.04.

Drozdowska Agnieszka, Kobiety z ziem Królestwa Polskiego i Obwodu Białostockiego podczas pierwszej wojny światowej, praca mag., Uniwersytet w Białymstoku, Białystok : Uniw. Dysert, 2017.

Dufrat Joanna, Stan badań nad dziejami kobiet w Polsce. I wojna światowa, okres międzywojenny, II wojna światowa [w:] Dzieje kobiet w Polsce. Dyskusja wokót przyszłej syntezy, red. Krzysztof Makowski, Poznań : Wydawnictwo Nauka i Innowacje, 2014, s. 123-131, ISBN 978-83-6379547-4.

Dufrat Joanna, W służbie obozu marszałka Józefa Piłsudskiego. Zwiazek Pracy Obywatelskiej Kobiet (1928-1939), Kraków : Wydawnictwo Avalon T. Janowski, 2013, ISBN 978-83-7730-055-8.

Englund P., Piękno i smutek wojny. Dwadzieścia niezwykłych losów z czasu światowej pożogi, przeł. Emilia Fabisiak, Kraków : Wydawnictwo Znak, 2011, ISBN 978-83-240-1858-1.

Gawin Magdalena, Spór o równouprawnienie kobiet 1864-1919, Warszawa : Instytut Historii PAN, 2015, ISBN 978-83-7543-389-0.

Historia Białegostoku, red. Adam Dobroński, Białystok : Fundacja Sąsiedzi, 2012, ISBN 978-83-934373-0-6.

Korzeniowski Mariusz, Mądzik Marek, Tarasiuk Dariusz, Tułaczy Los: uchodźcy polscy $w$ imperium rosyjskim $w$ latach pierwszej wojny światowej, Lublin : Wydawnictwo UMCS, 2007, ISBN 978-83-227-2691-4.

Lata Wielkiej Wojny. Dojrzewanie do niepodległości 1914-1918, red. Daniel Grinberg, Jan Snopko, Grzegorz Zackiewicz, Białystok : Wydawnictwo Uniwersytetu w Białymstoku, 2007, ISBN 978-83-7431-142-7. 
Lechowski Andrzej, Okupacja 1915-1919. Cukierpuszki i herbaciane hale, [online] „Kurier Poranny”, 5.09.2015, [Dostęp: 7.06.2017]. Dostępny w World Wide Web: < http://bit.ly/2sCkaDL>.

Matusiewicz Andrzej, Kobiety w życiu społeczno-kulturalnym Suwałk przed 1914 rokiem [w:] Zachodnie wzorce $i$ wschodnie realia. Przedstawicielki elit prowincjonalnych w XIX i pierwszej połowie XX wieku, red. Małgorzata Dajnowicz, Białystok : Instytut Historii Uniwersytetu w Białymstoku; Drozdowo : Muzeum Przyrody, 2009, s. 103-124, ISBN 978-83-9242677-6.

Piotrowska-Marchewa Monika, Kobiety i filantropia. Uwagi o zaangażowaniu przedstawicielek polskich elit $w$ działalność dobroczynna XIX wieku [w:] Zachodnie wzorce i wschodnie realia. Przedstawicielki elit prowincjonalnych w XIX i pierwszej połowie XX wieku, red. Małgorzata Dajnowicz, Białystok : Instytut Historii Uniwersytetu w Białymstoku; Drozdowo : Muzeum Przyrody, 2009, s. 49-63, ISBN 978-83-924267-7-6.

Prymaka-Oniszk Aneta, Bieżeństwo 1915. Zapomniani uchodźcy, Wołowiec : Wydawnictwo Czarne, 2016, ISBN 978-83-8049-350-6.

Sierakowska Katarzyna, Śmierć - Wygnanie - Głód w dokumentach osobistych. Ziemie polskie $w$ latach Wielkiej Wojny 1914-1918, Warszawa : Wydawnictwo IH PAN, 2015, ISBN 978-83-63352-49-3.

Snopko Jan, Wstęp [w:] Wielka Wojna poza linia frontu, red. Daniel Grinberg, Jan Snopko, Grzegorz Zackiewicz, Białystok : Wydawnictwo Prymat, 2013, ISBN 978-83-87881-16-0.

Uchodźstwo polskie $w$ Rosji w latach I wojny światowej, oprac. Mariusz Korzeniowski, Krzysztof Latawiec, Dariusz Tarasiuk, Lubow Żwanko, Lublin : Wydawnictwo UMCS, 2016, ISBN 978-83-7784-916-3.

Urbanek Bożena, Idea opieki nad chorym na ziemiach polskich $w$ latach 1809-1914, Wrocław : Oficyna Wydawnicza Arboretum, 2003, ISBN 8386062-07-X.

Wawrzykowska-Wierciochowa Dionizja, $W$ kręgu miłości $i$ bohaterstwa. $Z$ dziejów humanitaryzmu polskiego i prekursorów Czerwonego Krzyża, Warszawa : Państwowy Zakład Wydawnictw Lekarskich, 1965.

Wielka Wojna poza linia frontu, red. Daniel Grinberg, Jan Snopko, Grzegorz Zackiewicz, Białystok : Wydawnictwo Prymat, 2013, ISBN 978-8387881-16-0. 